\title{
Commentary
}

\section{Six Patients an Hour}

\author{
Richard V. Ohmart, M.D. \\ Oakley, KS
}

This morning I went to a doctor's office as a patient. No great problem, the nurse practitioner was instructing me to lose weight. The building was where I had worked until a stroke forced me to retire ten years ago. As I sat in the waiting room, I heard a physician being recruited to the practice say that no doctor could see six patients an hour. The receptionist had worked for me for years and she smiled as she said "You did, and did a good job at it." As I thought back, I agreed "Yes, I did."

As a fourth-year student, I had spent my precepteeship in Oakley with Jim Marchbanks, MD, the only physician in town. I spent two weeks in Oakley after I graduated so Dr. Marchbanks could have a vacation with his family. I served an internship in Wesley Hospital, now Wesley Medical Center, in Wichita. After completing that year, I moved to Oakley to join Jim in practice. There was no family practice residency at that time. Jim was an excellent physician and teacher; I was certain I could learn from him while earning a living. In 1963, he paid me $\$ 1000$ a month. I was wealthy! Six months later, he told me I was seeing enough patients that he could pay me $\$ 1200$ monthly.

After eight months, Jim and I were as busy as we wanted; Jim actually was busier than he cared. Then, Jim died unexpectedly. I was now the only physician in a community of about 3000. How was I to handle the practice we had built? I just worked hard!

The physicians I had tried to emulate at the University of Kansas Medical Center and Wesley Hospital worked hard. Those in Wichita made morning hospital rounds, spent the day in their offices, then made evening hospital rounds. However, there were two or three physicians sharing their practices. They shared evenings and weekends off.

I knew I could work hard, although there would be no one to share time off. Jim and I used to arrive at the hospital about 8:00 am. If we had surgery, we arrived at 7:30 or a bit earlier. By 9:00 am, we had completed rounds and had coffee with the hospital administrator, the head nurse, and anyone else who wandered in. We planned to be at the office by 9:30. Actually, we were already behind by coffee time. We usually got to our office about 10:00 am. We scheduled our last morning patients at 11:30, hoping to be finished by 12:00. Since we started late, we finished late. We often left the office at 12:30 or 1:00.

We had lunch and time for a short nap. We scheduled afternoon patients from 2:30 to 5:00 $\mathrm{pm}$. We allotted fifteen minutes per visit, thirty minutes for a complete physical exam. We never refused walk-ins and rarely left the office before $5: 30$ or $6: 00 \mathrm{pm}$, then making evening rounds at the hospital. I was happy to be home by $6: 30 \mathrm{pm}$.

After Jim's death, I started my day at 7:30 am. I was not a surgeon, so that was not much different. Morning rounds and fifteen minutes for coffee at the hospital got me to my office by 9:00 and allotted fifteen minutes per routine visit. After appointments were completed, I had walk-ins and morning phone calls to return. I planned on having a half hour for lunch, a half hour nap, and returned to the office at 2:00 pm. In the afternoon, I scheduled a visit every ten minutes. By this time, I had taken care of my patients/friends for years so I rarely had to look at 
an old chart to know what it contained. By the end of the afternoon, I had most of my charting left to do after the appointments were completed (my charts were quite a bit shorter then), then make phone calls and evening rounds. I usually got home by $6: 30$ or 7:00 pm.

Deliveries and other emergencies interrupted my office hours, evenings, and weekends, but this was to be expected. The physicians I knew in Wichita and the other doctors in Western Kansas all had similar schedules. It was my practice and I loved it. It was my office, my employees, and my schedule. And they were my patients. I knew them, took care of them, and cried as they died. I felt that I should always be willing to come when summoned. My wife was not as happy about this as I was, but she had grown up with a hardworking father and had seen other doctors' families' live as we did. She built her own life around my practice.

I often had a medical or a physician assistant student with me. That freed me for a bit of time to do my charting while a student saw a new patient. The hospital administrator hired a locums tenens physician to cover the community one weekend a month so I could be off call from Friday evening to Sunday evening. He hired a physician for a week or so to give me a summer vacation. I hired a physician assistant for six years. I had a partner for five years, then he left. I was again alone.

In 1972, we formed a Rural Healthcare Clinic (RHC). One of the requirements was to have a mid-level practitioner so from 1972 until my stroke in 2001, I worked with at least one nurse practitioner. From 1994 to 1998, another physician joined our RHC. Even after he left, two nurse practitioners worked with me.

For about ten years, I worked alone with only an occasional student in Oakley. I think I provided better than average care for my patients. Many of the students asked me if he or she had to work as hard as I did. My response was "No. I had planned on practicing with a partner. He died far too soon. I was thrown into a community where I was the only physician. I was unable to recruit a physician to remain in Oakley. While I had not planned on my solo practice, I always loved it. But you certainly don't have to live my life!"

Thus I practiced, and we lived, in Oakley for years. Our three children grew up, went to colleges, and left Oakley. I continued to practice until I fell on the ice and sustained a head injury and stroke forcing me to retire. But I would yet be practicing in Oakley if possible. 